\title{
Atıf Analizi: Hacettepe Üniversitesi Kütüphanecilik Bölümü Tezlerinde Atıf Yapılan Kaynaklar
}

\author{
Citation Analysis: Sources Cited in Dissertations \\ Completed at Hacettepe University Department of \\ Librarianship
}

\section{Umut $\mathrm{Al}^{*}$ ve Yaşar Tonta**}

\begin{abstract}
Öz
Bibliyometri, yayınların ya da belgelerin yazar, konu, yayın bilgisi, atıf yapılan kaynaklar, vb. gibi belirli özelliklerinin niceliksel olarak analizi ile ilgilenir. Elde edilen bibliyometrik verilere dayanarak çeşitli disiplinlerde bilimsel iletişim sürecinin nasıl gerçekleştiği araştırılabilir. Bu araştırmada Hacettepe Üniversitesi Kütüphanecilik Bölümünde 1974-2002 yılları arasında yapılan 100 adet yüksek lisans ve doktora tezi bibliyometrik özellikleri açısından incelenmektedir. Bölümde yapılan tezler ortalama 171 sayfa uzunluğundadır. Tezlerdeki ortalama atıf sayısı ise 70'tir. Doktora tezleri ortalama 275 sayfa, yüksek lisans tezleriyse 142 sayfa uzunluğundadır. Doktora tezlerindeki ortalama atıf sayısı (132) yüksek lisans tezlerindeki ortalama atıf sayısından (53) yaklaşık 2,5 kat daha yüksektir. Tezlerde yer alan toplam 7019 atıfın \%50'si kitaplara, \%42'si dergilere, \%3'ü tezlere, \%3'ü elektronik yayınlara, \%2'si ise diğer yayınlara (yayımlanmamış makaleler, görüşmeler, arşiv belgeleri) yapılmıştır. En çok atıf yapılan dergiler sıralamasında Türk Kütüphaneciliği, Resmî Gazete, College \& Research Libraries, Library Trends, Library Journal, Journal of the American Society for Information Science ve Unesco Bulletin for Libraries dergileri başta ge/mektedir. Toplam atıfların \%32'si 4, \%67'si 38 dergide yayımlanan makalelere yapılmıştır. Yabancı dergilere yapılan atıfların dağıımı Brad-
\end{abstract}

\footnotetext{
* Arş.Gör.; Hacettepe Üniversitesi Bilgi ve Belge Yönetimi Bölümü 06532 Beytepe-Ankara (umutal@hacettepe.edu.tr).

** Prof.Dr.; Hacettepe Üniversitesi Bilgi ve Belge Yönetimi Bölümü 06532 Beytepe-Ankara (tonta@hacettepe.edu.tr).
} 
ford'un Saçılım Yasasına uygunluk göstermektedir. Tezlerde atıf yapılan kaynakların yarı yaşamı (half-life) dokuz yıldır. Yüksek lisans tezlerinde atıf yapılan kaynaklar doktora tezlerinde atıf yapılan kaynaklardan daha gençtir. Tezlerde atıf yapılan kaynakların büyük bir çoğunluğu tek yazarlıdır. Araştırmada elde edilen bibliyometrik bulgular kütüphane koleksiyonlarının değerlendirilmesinde ve kütüphanecilik alanında çekirdek dergi koleksiyonu oluşturulmasında kullanılabilir.

Anahtar sözcükler: Tezler-Bibliyometrik özellikler, Atıf analizi, Literatür eskimesi.

\section{Abstract}

Bibliometrics deals with the quantitative analysis of some distinct characteristics (i.e. authorship, subject, publication information, and cited sources) of publications or documents. The process of scientific communication in various fields can be investigated using bibliometric data obtained in such studies. This paper analyzes the bibliometric features of 100 master's and doctoral dissertations completed at the Department of Library Science of Hacettepe University between 1974 and 2002. An average dissertation was 171 pages long and contained 70 citations. Doctoral dissertations were twice as long as master's dissertations (275 pages as opposed to 142 pages). Similarly, the average number of citations in a doctoral dissertation was 2.5 times higher than that of a master's dissertation. Monographs received half of all citations (7019) while journals did $42 \%$, dissertations and electronic publications $3 \%$ each, and "other" documents such as unpublished manuscripts $2 \%$. The Türk Kütüphaneciliği (the journal Turkish Librarianship), Resmî Gazete (Official Gazette), College \& Research Libraries, Library Trends, Library Journal, Journal of the American Society for Information Science and Unesco Bulletin for Libraries were among the most frequently cited journals. Articles that appeared in the top four and top 38 journals received $32 \%$ and $67 \%$ of all citations, respectively. The distribution of citations to foreign journals fits the Bradford's Law of Scattering. The mean half-life of sources cited in dissertations was 9 years. Sources cited in master's dissertations were younger than those of doctoral dissertations. The great majority of cited resources in dissertations had single authorship. Findings obtained in this study can be used to evaluate the library collections as well as to develop a core journals list in librarianship.

Keywords: Dissertations-Bibliometric features, Citation analysis, Literature obsolescence. 


\section{Giriş}

Bir düşüncenin kaynağını açıklama ya da "atıf yapma" (citation) kavramı, matbaanın bulunmasından sonra, Rönesans döneminde gelişmiştir. Dipnotların ve referansların kullanım tarihi kesin olarak bilinmemekle birlikte, bu konuda Oxford English Dictionary'de verilen ilk örnek William Savage'in A Dictionary of the Art of Printing (1841) adlı çalışmasıdır. Dipnota benzeyen örneklerin ilk kullanım tarihi 16. yüzyıla kadar gitmektedir (White, 1985).

Atıf yapmanın temel işlevi, atıf yapan ile atıf yapılan belge arasında bir bağ kurmaktır. Atıfların başlıca rolü daha önceki araştırmaları tanıtmaktır. Bunun yanı sıra, ilgili çalışmaları değerlendirme, kanıt gösterme, yöntemi tanımlama, ilgili yayınlardan haberdar olduğunu gösterme, daha geniş okuma olanağı sağlama vb. gibi nedenlerle de başka kaynaklara atıf yapılmaktadır (White, 1985, ss. 38-39; Smith, 1981, ss. 84-85).

Atıf dizinleme (citation indexing) ilk olarak 1873 yılında Shepherd's Citations adlı kaynağın yayımlanmasıyla başlamıştır. 20. yüzyılda bibliyografik uygulamaların standartlaştırılması atıf dizinlemesinin nesnelliğini ve güvenilirliğini artırmıştır. 1950'lerin ortasında Eugene Garfield, atıf dizinlemesinin dergi kullanımı, sık kullanılan kaynakların düzenlenmesi ve yönetimi, tarihsel ve toplumbilimsel araştırmaların yapılması ve literatür artışıyla ilgili güvenilir bilgiler elde etme konusundaki önemini farketmiştir. Nitekim Bilimsel Bilgi Enstitüsü (Institute for Scientific Information) Garfield'ın önderliğinde 1961 yılında önce Science Citation Index'i, daha sonra da Social Science Citation Index'i (1973) ve Arts and Humanities Citation Index'i (1978) yayımlamaya başlamıştır (White, 1985, s. 39). Günümüzde adı geçen atıf dizinlerine web aracılığıyla (www.isinet.com) da erişilebilmektedir.

Atıf analizi (citation analysis) araştırmalarına son yıllarda yoğun bir ilgi gösterilmektedir. Bu tür araştırmalarda yazar verimliliği, yayınların kullanımı, literatürün yaşlanması gibi konular ele alınmaktadır. Bu bağlamda atıf analizi araştırmaları, örneğin, belli bir konudaki en verimli araştırmacıları ve en sık kullanılan kaynakları belirlemeye, kaynakların ne kadar süreyle kullanıldığını saptamaya ve çekirdek dergi koleksiyonu oluşturmaya yardımcı olmaktadır. Atıf analizi araştırmalarında elde edilen bulgulardan hem bilimsel araştırma etkinliklerinin değerlendirilmesinde, hem de kütüphane koleksiyonlarının geliştirilmesinde ve yönetiminde yararlanılmaktadır. 
Atıf analizi araşıırmalarının daha çok bilimsel dergilerde yayımlanan makaleler üzerinde yapıldığı gözlenmektedir. Ancak üniversite öğrencilerinin bilimsel araştırma yapabilme yeteneklerini belgeleyen yüksek lisans ve doktora tezleri de atıf analizi araştırmalarında kullanılmaktadır. Tezlerde atıf yapılan kaynakların içeriği ile bilimsel makalelerde atıf yapılan kaynakların içeriği birbirleriyle ilişkilidir. Yüksek lisans ve doktora tezleri de bilim ve teknolojinin gelişmesine katkıda bulunmakta ve toplumsal yarar sağlamaktadır. Bu bakımdan tezler üzerinde yapılan atıf analizi çalışmaları da belli bir bilim disiplininde öne çıkan araştırmacıları ve yararlanılan kaynakları göstermesi açısından önem taşımakta, koleksiyon geliştirme ve yönetiminde kullanılmaktadır.

1934 yılında formüle edilen Bradford'un Saçılım Yasası "belirli bir konudaki literatürün dergilerde nasıl saçıldığını ya da dağıldığını göstermektedir" (Garfield, 1980, s. 5). Garfield, Bradford Yasasını şöyle yorumlamaktadır: "Herhangi bir konuda bir kaynakça derlemek isterseniz, bu konu ya da disiplindeki makalelerin önemli bir yüzdesini (1/3) karşılayan daima küçük bir grup çekirdek dergi vardır. Daha büyük ikinci bir grup dergi ise o konudaki makalelerin diğer üçte birini, çok daha büyük bir grup dergi ise son üçte birini karşılar" (Garfield, 1980, s. 6). Başka bir deyişle, bu yasaya göre, belirli bir konudaki dergiler eşit sayıda makale içeren gruplara ayrıldığında bu gruplar azalan verimlilik ilkesine göre sıralanmaktadır. Bu nedenle çok sayıda makale az sayıda çekirdek dergide yayımlanmaktadır (Tonta, 2002, s. 304). Bradford Yasası atıf yapılan makalelerin dergilerdeki dağılımına bakılarak belirli bir konuda en çok makale yayımlayan çekirdek dergilerin saptanmasında kullanılmaktadır.

Bir derginin bir yıl boyunca aldığı atıf sayısının o derginin önceki iki yılda yayımladığı makale sayısına oranı "etki faktörü" olarak tanımlanmakta ve o dergide yayımlanan makalelerin genel kalitesini gösteren bir ölçüt olarak kullanılmaktadır (Rousseau, 1988, s. 249). Bir dergide yayımlanan makalelerin aldığı atıf sayısı nasıl o derginin etki faktörünü belirleyen bir gösterge olarak kullanılıyorsa, o dergide yayımlanan makalelerin kütüphane kullanıcıları tarafından hangi sıklıkla istendiği de önemli bir gösterge olarak kullanımaktadır. Kullanıcılar tarafından istenen makalelerin dergilerdeki dağılımına bakarak çekirdek dergi koleksiyonları geliştirilmektedir. 
Atıf analizi çalışmaları çeşitli teknikler kullanılarak gerçekleştirilmektedir. $\mathrm{Bu}$ tekniklerin en yaygın kullanım alanı bulanları "bibliyografik eşleştirme" (bibliographic coupling) ve "ortak atıf"tır (co-citation). Farklı iki kaynakta aynı yayına atıf yapılması bibliyografik eşleştirme, bir kaynakta farklı iki yayına atıf yapılması ise ortak atıf olarak tanımlanır (Garfield, 1988). Bibliyografik eşleştirme ve ortak atıf, konu ya da diğer bazı özellikler (örneğin, otorite) açısından yayınların birbirlerine benzerliği hakkında bir fikir vermektedir.

Bilimsel dergilerde yayımlanan makalelerde güncel yayınlara daha fazla atıf yapıldığı gözlenmektedir. Konulara ve yayın türlerine göre atıf yapılan yayınların ortanca yaşı değişiklik göstermesine rağmen, yayınlar yaşlandıkça giderek daha az atıf almaktadırlar (Meadows, 1967; Earle ve Vickery, 1969). Benzeri bir biçimde, yıllar geçtikçe belirli bir literatürdeki kaynakların kullanımı azalmakta, yani ilgili literatür yaşlanmakta ve güncelliğini yitirmektedir. "Literatür eskimesi" (obsolescence) ya da "literatür yaşlanması" (ageing) olarak da adlandırılan bu durumu göstermek için "yarı yaşam" (half-life) ya da "eskime" adı verilen bir ölçü kullanılmaktadır. Yarı yaşam, "atıf ya da istek yapılan kaynakların ortanca yaşı" olarak tanımlanmaktadır (Earle ve Vickery, 1969, s. 132; Line, 1970, s. 46). Başka bir deyişle, atıf yapılan kaynaklar yayın yıllarına göre sıralandığında, atıfların yarısına gelen yıl söz konusu literatürün yarı yaşamını vermektedir (Tonta, 2002, s. 306). Yayınların atıf sıkığına bakılarak ölçülen yaşlanma ile kütüphanede kullanım sıklıklarına bakılarak ölçülen yaşlanma arasında anlamlı bir ilişki olmamakla birlikte, yayınların güncel olup olmaması koleksiyon geliştirme kararlarında önemli bir ölçüt olmaya devam etmektedir.

Bu araştırmada Hacettepe Üniversitesi Kütüphanecilik Bölümünde yapılan doktora ve yüksek lisans tezleri bibliyometrik özellikleri açısından incelenmekte, tezlerin kaynakçalarında yer alan atıfların dergilere göre dağııımının Bradford Saçılım Yasasına uyup uymadığı test edilmekte ve kütüphanecilik literatürünün yaşlanma hızı hesaplanmaktadır.

\section{Önceki Çalışmalar}

Bilinen ilk atıf analizi çalışması 1927 yılında yayımlanmıştır. P.L.K. Gross ve E.M. Gross adlı araştırmacılar Journal of the American Chemical Society adlı dergide yayımlanan makalelerin kaynakçalarını inceleyerek diğer yayın- 
lara yapılan atıfları saptamışlar ve bu sonuçlardan yararlanarak ABD'deki bir kolej kütüphanesi için dergi aboneliği ve eski sayıları satın alma politikası oluşturmuşlardır (White, 1985, s. 39).

Bir dergide yayımlanan makalelere yapılan atıfların, o derginin niteliklerini nesnel olarak ölçmek için kullanılabileceğini savunan I.N. Sengupta, bu savını tıp konusunda test etmiş ve Annual Review of Medicine adlı kaynak eserde 1965-1969 yıllarında yayımlanan makalelerde yapılan atıfları inceleyerek en çok atıf yapılan 275 tıp dergisinden oluşan bir liste yayımlamıştır (Sengupta, 1974).

Tezlere yönelik olarak ise farklı alanlarda farklı araştırmaların yapıldığı görülmektedir (Buttlar, 1999; Edwards, 1999; Gooden, 2001; Herubel, 1991; Kushkowski, Parsons ve Wiese, 2003; Kuyper-Rushing, 1999; LaBorie ve Halperin, 1976; Sylvia ve Lesher, 1995; Walcott, 1991, 1994; Zipp, 1996). Söz konusu araştırmalar bibliyometrik analizler, tezlerin içerik analizi ve konu dağılımları, tezlerde en sık atıf yapılan kaynaklar, kullanılan araştırma yöntemleri ve veri toplama teknikleri gibi özellikler üzerinde yoğunlaşmaktadır.

Buttlar (1999), 61 kütüphanecilik ve bilgibilim tezinde en çok hangi dergilerin ve yayın türlerinin kullanıldığını ve atıf yapılan kaynakların güncelliğini araştırmıştır. Araştırmada dergilerdeki makalelere yapılan atıf sayısının diğer yayın türlerine (kitap, tez, vb. gibi) yapılan atıfların toplamından daha fazla olduğu ortaya çıkmıştır. Atıf yapılan toplam 815 farklı dergi içinde en sık atıf yapılan iki derginin College \& Research Libraries ve Journal of the American Society for Information Science olduğu saptanmıştır (Buttlar, 1999, s. 236).

LaBorie ve Halperin (1976), 1969-1972 yılları arasında Amerikan kütüphanecilik okullarında tamamlanan tezlerde yapılan atıflar arasından örneklem almak yoluyla gerçekleştirdikleri araştırmada, tezlerde kitaplara yapılan atıfların (\%43) dergilere yapılan atıflardan iki kat daha fazla (\%23) olduğunu; yayımlanmamış materyallere (arşiv belgeleri, el yazmaları, görüşmeler) yapılan atıf sayısının neredeyse dergilere yapılan atıf sayısı kadar yüksek olduğunu bulmuşlardır (LaBorie ve Halperin, 1976, s. 278). Tarihle ilgili tezlerde yapılan atıf sayısının diğer konularda (yönetim, kaynaklar, kütüphane hizmetleri, teknik işlemler, otomasyon) yapılan tezlerdeki atıf sayısından yüksek olduğu saptanmıştır (LaBorie ve Halperin, 1976, s. 274). Tezlerdeki toplam atıfların \%24'ünün son beş yılda yayımlanan kaynaklara yapıldığı, 20 yaşın- 
dan daha yaşlı kaynaklara yapılan atıfların toplam atıfların \%51'ini oluşturduğu görülmüştür (LaBorie ve Halperin, 1976, s. 280).

Diğer bilim dallarında tamamlanan tezlerde yapılan atıfların analizinden koleksiyon yönetme ve geliştirmede bir araç olarak yararlanılabileceğini gösteren çalışmalar bulunmaktadır (Edwards, 1999; Sylvia ve Lesher, 1995; Zipp, 1996). Örneğin, psikoloji tezlerinde en çok hangi dergilerde yayımlanan makalelere atıf yapıldığı ve atıf yapılan dergilerin kütüphanede bulunup bulunmadığı araştırımış, kütüphanede bulunan dergilerin maliyetleri ile tezlerde yapılan atıflar ve kütüphane içi dergi kullanımlarına bakılarak "maliyetetkinlik” ölçümü yapılmıştır (Sylvia ve Lesher, 1995). Söz konusu verilerin dergilere abone olma kararı verilirken kullanılabileceği, ancak atıf analizi çalışmalarının dergi kullanımını tam olarak göstermeyeceği vurgulanmaktadır (Sylvia ve Lesher, 1995, ss. 315-317).

Müzik kütüphanelerinde çekirdek dergi koleksiyonunu saptamak amacıyla müzik tezlerinde yapılan atıflar incelenmiş ve müzik alanında kitapların (\%41) süreli yayınlardan (\%29) daha fazla kullanıldığı ortaya çıkmıştır (Kuyper-Rushing, 1999, s. 160). Felsefe alanında yapılan tezlerde kitaplara yapılan atıfların sayısı dergilerinkinden üç kat daha fazladır (Herubel, 1991, s. 67). Sosyal bilimler, güzel sanatlar ve insan bilimlerinde de kitap türü yayınlara daha fazla atıfta bulunulduğu aktarılmaktadır (Kushkowski, Parsons ve Wiese, 2003, s. 472).

Fen bilimlerinde yapılan tezlerde ise dergilerde yayımlanan makalelere daha fazla atıf yapılmaktadır. Kimya alanındaki doktora tezlerinde yer alan atıfların \%86'sı dergilerde yayımlanan makalelere yapılmıştır (Gooden, 2001). Bu oran yer bilimlerinde \%80, biyolojide \%90 civarındadır (Walcott, 1991, s. 9; Walcott, 1994, s. 4).

1973-1992 yılları arasında lowa Devlet Üniversitesinde yapılan yüksek lisans ve doktora tezlerinde yapılan atıflardan bir örneklem seçilmiş, örneklemde yer alan toplam 9102 atıfın \%64'ünün dergilerde yayımlanan makalelere, \%24'ünün ise kitaplara yapıldığı, atıf yapılan kaynakların \%85'inin üniversite kütüphanesinde olduğu saptanmıştır. Aynı araştırmada mühendislik ve sosyal bilimlerde yapılan tezlerde güzel sanatlar ve insan bilimlerine oranla daha güncel kaynaklara atıf yapıldığı ortaya çıkmıştır (Kushkowski, Parsons ve Wiese, 2003, ss. 465-467). 
Son yıllarda ülkemizde de bibliyometrik çalışmalara olan ilginin arttığı gözlenmektedir (Yurtsever, Gülgöz, Yedekçioğlu ve Tonta, 2002, 2001; Tonta ve İlhan, 2002, 1997; Tonta, 2000; Yurtsever ve Gülgöz, 1999; Denkel, Kâğıtçıbaşı, Pak ve Pamuk, 1999). Ancak atıf analizi ile ilgili çalışmalara daha seyrek rastlanmaktadır. Yapılan bir araştırmada ülkemizdeki tıp kütüphanelerinin abone oldukları dergilerin listeleri yukarıda anılan Sengupta'nın çekirdek dergi listesiyle karşılaştırılmıştır. Abone olunan dergilerin eski sayılarının eksik olduğundan hareket edilerek rastgele 30 tıp dergisi seçilmiş ve bu dergilerin 1950, 1960 ve 1970 yıllarına ait birer sayıları rastgele seçilerek her birinden 10'ar atıf kaydedilmiştir. Hacettepe Üniversitesi Tıp Merkezi Kütüphanesinin dergi abonelik listesi Sengupta'nın çekirdek dergi listesiyle \%89 uygunluk göstermesine rağmen, örneklemde yer alan atıfların yapıldığı dergilerin eski sayılarının sadece \%57'sinin Hacettepe Üniversitesi Tıp Merkezi Kütüphanesinde bulunduğu anlaşılmıştır (Kum, 1974, ss. 4950). Bir başka araştırmada tıp ve sağlık bilimlerindeki etki faktörü en yüksek 21 derginin çoğunun Ankara'daki üniversite kütüphanelerinde ve Ulusal Akademik Ağ ve Bilgi Merkezi'nde (ULAKBIM) bulunabildiği saptanmıştır (Alkan, 1999). Temel ve uygulamalı bilim dallarında ise Ankara'daki kütüphanelerin etki faktörü yüksek 146 derginin yarısından fazlasına $(\% 61,6)$ abone oldukları anlaşımıştır (Alkan, 1998).

Kütüphanecilik literatürü ile ilgili ülkemizde yapılan bibliyometri çalışmalarında genellikle dergiler incelenmiştir (Çakın, 1980, Gürdal, 2002, Kurbanoğlu, 1996; Tonta, 2002; Yılmaz, M., 2000). 1952-1971 yılları arasında Türk Kütüphaneciler Derneği Bülteninde yayımlanan makaleler yazar ve konu yönünden incelenmiş, kütüphane türleri üzerine daha fazla makale yazıldığı görülmüştür (Çakın, 1980, s. 57). Farklı yıllarda Türk Kütüphaneciliği dergisinde yayımlanan makaleler ve bu makalelerde atıf yapılan kaynaklar üç ayrı çalışmada incelenmiştir (Gürdal, 2002; Kurbanoğlu, 1996; Tonta, 2002). Toplam atıfların \%27'si ile \%33'ünün en sık atıf yapılan ilk beş dergide yayımlanan makalelere yapıldığı anlaşılmaktadır (Tonta, 2002, s. 303; Kurbanoğlu, 1996, s. 109). Ankara, Hacettepe ve İstanbul Üniversitelerinin Kütüphanecilik Bölümlerinde çalışan öğretim elemanları tarafından Türk Kütüphaneciliği ve Kütüphanecilik Dergisinde yayımlanan toplam 73 makalede yapılan atıflar yazarların çalıştıkları üniversitelere göre sınıflandırılmış, aynı bölümde çalışan öğretim üyelerinin birbirlerinin yayınlarına daha sık atıf yapma eğilimi gösterdikleri ortaya çıkmıştır (Yılmaz, M., 2000). 
Sosyal bilimlerle ilgili genel bir bibliyometrik çalışmada 1970-1999 yılları arasında Social Science Citation Index'te dizinlenen Türkiye adresli kütüphanecilikle ilgili 29 yayında yayın başına ortalama yazar sayısı 1,3 olarak bulunmuştur. Söz konusu yayınların 12 farklı dergide yayımlandığı, bu dergilerin etki faktörleri ortalamasının $(0,783)$ Journal Citation Reports'da (1998) listelenen toplam 54 derginin etki faktörü ortalamasından $(0,488)$ daha yüksek olduğu, 29 yayından 20'sine uluslararası literatürde toplam 43 atıf yapıldığı (ortalama 2,15) saptanmıştır (Yurtsever ve diğerleri, 2001; Gülgöz, Yedekçioğlu ve Yurtsever, 2002).

Ülkemizde kütüphanecilik alanında yapılan tezler ile ilgili atıf analizi çalışmalarının sayısı ise fazla değildir (Bayram, 1998; Gökkurt, 1997a; Gökkurt, 1997b). Aynı kişiye ait olan bu çalışmalar yazarın doktora tezinde kullandığı verilere dayanmaktadır. Kütüphanecilik alanında tamamlanan 17 doktora tezinin kaynakçalarında atıf yapılan 800 kaynak incelenmiş, dergilere yapılan atıfların \%42'sinin en sık atıf yapılan ilk beş dergiye (Türk Kütüphaneciliği, College \& Research Libraries, Library Trends, Journal of the American Society for Information Science, Information Processing \& Management) yapıldığı saptanmıştır (Gökkurt, 1997b, s. 159).

Hacettepe, Ankara ve İstanbul Üniversitelerinin Kütüphanecilik Bölümlerinde yapılan tezlerde en sık kullanılan araştırma yönteminin betimleme (survey) yöntemi olduğu bulunmuştur (Altınörs, 1983, s. 66). 1974-1997 yılları arasında sadece Hacettepe Üniversitesi Kütüphanecilik Bölümünde yapılan tezlerin incelendiği bir araştırmada, tezlerin genellikle bir kütüphane türü (halk kütüphaneleri, üniversite kütüphaneleri vd.) ile ilişkilendirildiği, bazı konularda pek az tez yapıldığı ortaya çıkmıştır (Yılmaz, B., 1997, ss. 197-198).

\section{Yöntem}

Bu çalışmanın amacı Hacettepe Üniversitesi Kütüphanecilik Bölümünde yapılan tezlerin bibliyometrik özelliklerini incelemek ve tezlerde en sık atıf yapılan kaynakları saptamaktır. Araştırmamızda şu sorulara yanıt aranmıştır:

Kütüphanecilik tezlerinde en sık atıf yapılan kaynak türü (kitap, dergi vb. gibi) hangisidir?

- Kütüphanecilik tezlerinde en sık atıf yapılan dergiler hangileridir? 
- Bir dergide yayımlanan makalelere yapılan atıf sayısıyla o derginin etki faktörü arasında bir ilişki var mıdır?

- Dergilere yapılan atıfların dağılımı Bradford'un Saçılım Yasasına uymakta mıdır?

- Yüksek lisans tezleri ile doktora tezleri atıf yönelimleri açısından birbirinden farklı mıdır?

- Kütüphanecilik literatürünün yaşlanma hızı nedir?

- Yüksek lisans tezleri ile doktora tezlerinde atıf yapılan kaynakların yaş ları birbirinden farklı mıdır?

Çalışmanın verileri atıf analizi tekniğinden yararlanılarak toplanmış ve değerlendirilmiş̧tir. Atıf analizine dayanan çalışmalarda yayınlarda yararlanılan kaynaklar araştırmanın verileri olarak kabul edilmekte, bu veriler incelenerek çeşitli çıkarsamalar yapılmaktadır. Atıf analizi çalışmalarında kimi zaman daha önce sözü edilen bazı bibliyometrik yasalara (Bradford, Lotka, Zipf vb. gibi) uygunluk test edilmekte, kimi zaman da veriler üzerinde çeşitli istatistiksel testler uygulanmaktadır (Broadus, 1987, s. 128).

Araştırma sorularını yanıtlamak için Hacettepe Üniversitesi Kütüphanecilik Bölümünde 1974-2002 yılları arasında yapılan 100 yüksek lisans ve doktora tezi ${ }^{1}$ önce bibliyometrik özellikleri (yıl, sayfa sayısı, danışman vb. gibi) açısından, daha sonra da tezlerde atıf yapılan kaynaklar (tür, dil, yazarlık) açısından incelenmiştir.

Tezlerde atıf yapılan kaynaklar kitap, makale, elektronik yayın, tez ve diğer yayınlar kategorilerine ayrılmıştır. Kitap, teknik rapor ve bildiri kitaplarına yapılan atıflar "kitap"; bilimsel ve popüler dergiler ile günlük-haftalık gazetelere yapılan atıflar "dergi"; veri tabanlarında yer alan makalelere ve web sitelerine yapılan atıflar "elektronik yayın" (e-yayın); yüksek lisans, doktora ve doçentlik tezlerine yapılan atıflar "tez"; yayımlanmamış makalelere, görüşmelere, arşiv belgelerine yapılan atıflar "diğer yayınlar" altında sınıflandırılmıştır. $\mathrm{Bu}$ çalışmada tezlerin kaynakçalarında yer almasına rağmen Library Literature, Library \& Information Science Abstracts, elektronik veri tabanları gibi bir tezin içeriğinin oluşmasına doğrudan katkıda bulunmayan bibliyogra-

\footnotetext{
${ }^{1}$ Kütüphanecilik Bölümünde yapılan üç adet doçentlik tezi araştırmamızın kapsamı dışındadır.
} 
fik kaynaklar ile Imlâ Kılavuzu, Tez Yazım ve Basım Yönergesi gibi hemen hemen tüm tezlerde atıf yapılan kaynaklar değerlendirme dışı bırakılmıştır.

Geçmiş yıllarda yapılan bazı tezlerde sayfa altı dipnot tekniğinin kullanıldığı görülmüştür. Sayfa altı dipnot tekniğinin kullanıldığı tezlerde, aynı kaynağa birden fazla yapılan atıflar dikkate alınmamıştır. Bir tezde hem kaynakça hem de sayfa altı dipnotlar kullanıldıysa atıf yapılan kaynaklar ile ilgili istatistikler kaynakçaya dayanılarak oluşturulmuştur. Kaynakçalarda listelenen tüm yayınlara tezlerin metinlerinde atıf yapıldığı varsayılmıştır. Bazı tezlerde yardımcı kaynakçaların yer aldığı görülmüştür. Ancak yardımcı kaynakçalarda listelenen kaynaklara metin içinde atıf yapılmadığı için bunlar değerlendirmede dikkate alınmamıştır. Yayın yılı olmayan toplam dokuz atıf değerlendirme dışı bırakılmıştır.

Atıf yapılan kaynaklar yayın diline göre sınıflanmıştır. En sık atıf yapılan dergiler hem "Türkçe dergiler" hem de "yabancı dilde dergiler" olarak ayrı ayrı listelenmiştir. Yüksek lisans ve doktora tezlerinde atıf yapılan dergilerin en sık atıf yapılan dergi sıralamalarının birbirinden farklı olup olmadığı Spearman'ın sıra-ilişki katsayısıyla sınanmıştır. En sık atıf yapılan dergilerin sırasıyla ISI tarafından yayımlanan Journal Citation Reports'da (2002) verilen etki faktörleri arasında bir ilişki olup olmadığı test edilmiştir.

Tezlerde atıf yapılan dergilerin bazılarının adlarının zaman içinde değiştiği saptanmıştır. Değerlendirmenin sağlıklı yapılabilmesi için dergilerin eski ve yeni adlarına yapılan atıflar birlikte değerlendirilmiş ve veriler dergilerin en yeni adları altında verilmiştir (örneğin, 1952-1986 yılları arasında Türk Kütüphaneciler Derneği Bülteni, 1987'den beri ise Türk Kütüphaneciliği adıyla yayımlanan derginin verileri Türk Kütüphaneciliği altında sınıflanmıştır).

Atıfların çoğunun az sayıdaki çekirdek dergide yayımlanan makalelere yapıldığı düşüncesinden hareketle, tezlerde yararlanılan dergilerin Bradford'un Saçılım Yasasına uyup uymadığı test edilmiştir. Tezlerde atıf yapılan yayınların yıllarına bakılarak atıfların yarı yaşamı hesaplanmış ve kütüphanecilik literatüründe eskime olgusuna dikkat çekilmiştir. Yarı yaşam, belirli bir literatürde eskimeyi göstermek için kullanılmaktadır. Yarı yaşamın hesaplanmasına ek olarak, atıfların \%80 ve \%90 eskime yılları bulunmuştur. Belli bir literatürdeki atıfların \%90'ının söz konusu yıl ve öncesinde yayımlanan yayınlara yapıldığını göstermek için "\%90 eskime" ifadesi kullanılmaktadır. 
Tezlerde atıf yapılan kaynakların kaç yazarlı olduğu incelenmiş, ilk yazarın Türk ya da yabancı olmasına bakılarak atıflar ayrıca değerlendirilmiştir. Editörlü kitaplar, yazar belirtilmeyip eser adı verilenler ve tüzel kişiler "yazar yok" sınıfına sokulmuştur.

\section{Bulgular ve Yorum}

1974-2002 yılları arasında Hacettepe Üniversitesi Kütüphanecilik Bölümünde yapılan toplam 100 tezin 78'i yüksek lisans, 22'si ise doktora tezidir. Yüz tezin toplam sayfa sayısı 17.088, ortalama sayfa sayısı ise 171 'dir $(S=78){ }^{2}$ Yüksek lisans tezlerinde ortalama sayfa sayısı 142 iken doktora tezlerinde bu rakamın (275) neredeyse iki katına çıktığı görülmektedir (Tablo 1). En uzun tez 450 sayfalık bir doktora tezi, en kısa tez ise 45 sayfalık bir yüksek lisans tezidir.

Tezlerde atıf yapılan kaynak sayısı toplamı 7019, ortalaması ise 70 'tir $(S=58, \min .=10$, maks. $=355)$. Doktora tezlerindeki ortalama atıf sayısı (132) yüksek lisans tezlerinden (53) yaklaşık 2,5 kat daha fazladır. Tezlerin sayfa sayısı arttıkça yapılan atıf sayısının da çoğaldığı görülmektedir.

Tablo 1. Tezlerle Ilgili Bilgiler

\begin{tabular}{|c|c|c|c|c|c|c|c|}
\hline \multirow[b]{2}{*}{ Tez türü } & \multirow{2}{*}{$\begin{array}{c}\text { Tez } \\
\text { sayısı }\end{array}$} & \multicolumn{3}{|c|}{ Sayfa sayısı } & \multicolumn{3}{|c|}{ Atıf sayısı } \\
\hline & & $\mathrm{N}$ & $\bar{x}$ & $S$ & $\mathrm{~N}$ & $\overline{\bar{x}}$ & $S$ \\
\hline Yüksek lisans & 78 & 11048 & 142 & 48 & 4105 & 53 & 32 \\
\hline Doktora & 22 & 6040 & 275 & 77 & 2914 & 132 & 84 \\
\hline Toplam & 100 & 17088 & 171 & 78 & 7019 & 70 & 58 \\
\hline
\end{tabular}

Bölümün yüksek lisans ve doktora programlarına her yıl ortalama 10 öğrenci kabul edilmektedir. Ancak yıllara göre tamamlanan tez sayıları büyük dalgalanma göstermektedir (Şekil 1). Yıl başına düşen ortalama tez sayısı 3,4’tür (ortanca 3, mod 2). 1981 yılında hiç tez yapılmadığı, Bölümün ilk açılış dönemine rastlayan 1974-1975 ile 1993 yıllarında ise sadece birer tez yapıldığı görülmektedir. 1978 yılında 10, 1989 ve 1994 yıllarında ise yedişer

2Tezlerde kullanılan kâğıt boyutu, punto büyüklüğü ve satır aralığı genişliği gibi özelliklerin 19742002 yılları arasında aynı kaldığı varsayılmıştır. 
tez tamamlanmıştır. Bu rakamlar programa kabul edilen her üç öğrenciden ancak birinin yüksek lisans ve doktora derecesi alarak mezun olduğunu göstermektedir.

Şekil 1. Tezlerin Yıllara Göre Dağılımı $(N=100)$

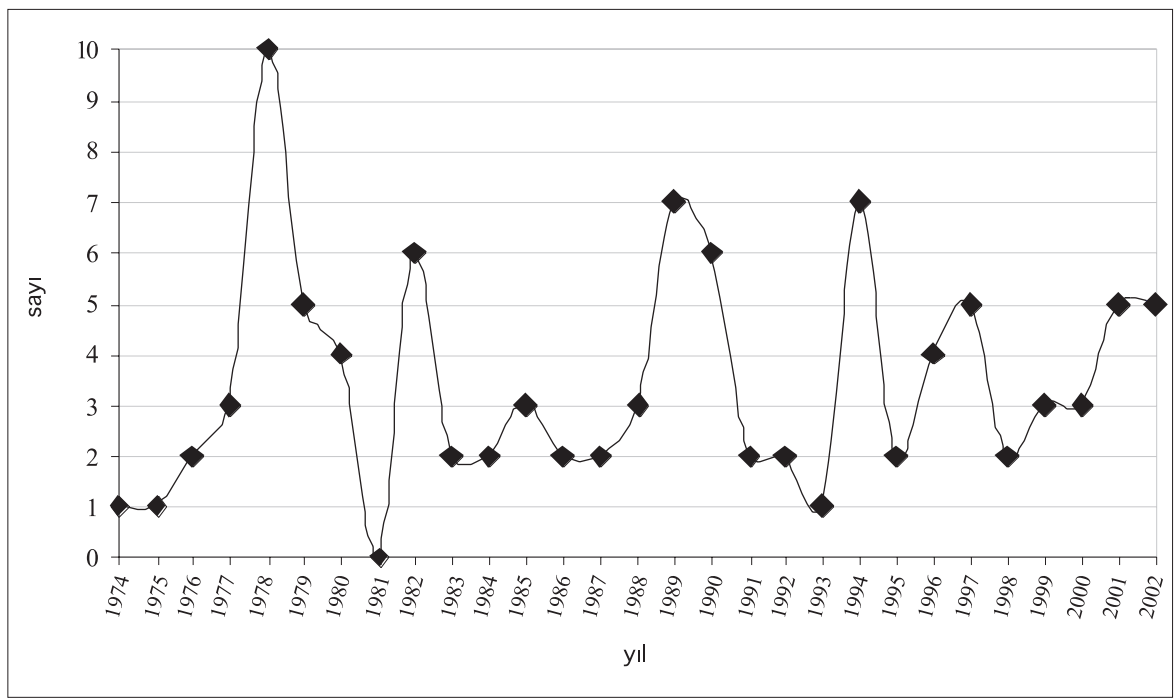

Bölümün kuruluşunu izleyen ilk yıllardan 1982 yılına kadar Bölümde tez yönetebilecek üç doktoralı öğretim üyesi (Adil Artukoğlu, İlhan Kum ve Nilüfer Tuncer) vardı. Bu nedenle, aslında Ankara Üniversitesi Dil ve TarihCoğrafya Fakültesi Kütüphanecilik Bölümü öğretim üyesi olan, ama Hacettepe Üniversitesi Kütüphanecilik Bölümünde de ilk kuruluş yıllarında ders veren Prof. Dr. Osman Ersoy, 1980 yılına dek toplam altı tez yönetmiştir. ${ }^{3}$ 19742002 yılları arasında Hacettepe Üniversitesi Kütüphanecilik Bölümünde yapılan 100 tezde 15 farklı öğretim üyesi danışman olarak görev yapmıştır. Tezlerin hemen hemen yarısı N. Tuncer ve I. Çakın'ın danışmanlığında yapılmıştır (Tablo 2).

3 Hacettepe Üniversitesi Bilgi ve Belge Yönetimi Bölümü öğretim üyesi Prof. Dr. Nilüfer Tuncer ile 3 Ekim 2003 tarihinde yapılan görüşme. 
Tablo 2. Tezlerin Danışmanlara Göre Dağılımı $(N=100)$

\begin{tabular}{lcccc}
\hline & \multicolumn{3}{c}{ Yönettiği tez sayısı } & \\
\cline { 2 - 4 } Danışman & Yüksek lisans & Doktora & Toplam & Birikimli \% \\
\hline Nilüfer Tuncer & 24 & 5 & 29 & 29 \\
İrfan Çakın & 15 & 4 & 19 & 48 \\
Tülin Sağlamtunç & 8 & 2 & 10 & 58 \\
İlhan Kum & 6 & 2 & 8 & 66 \\
Osman Ersoy & 1 & 5 & 6 & 72 \\
Gülbün Baydur & 5 & 1 & 6 & 78 \\
Adil Artukoğlu & 2 & 3 & 5 & 83 \\
Yaşar Tonta & 5 & - & 5 & 88 \\
Serap Kurbanoğlu & 4 & - & 4 & 92 \\
Nazan Uçak & 2 & - & 2 & 94 \\
Fahriye Gündoğdu & 1 & - & 1 & 95 \\
Salih Gürbüz & 1 & - & 1 & 96 \\
Inci Önal & 1 & - & 1 & 97 \\
Bülent Yılmaz & 1 & - & 1 & 98 \\
Bilinmiyor & 2 & - & 2 & 100 \\
\hline
\end{tabular}

aBölümde yapılan iki tezin danışmanları saptanamamıştır.

\section{Atıf Analizi}

Tezlerin kaynakçalarında yer alan toplam 7019 atıfın \%50'si kitaplara, \%42'si dergilere, \%3'ü tezlere, \%3'ü e-yayınlara, \%2'si ise diğer yayınlara yapılmıştır (Tablo 3). Atıf yapılan her iki kaynaktan biri kitap formatındadır. Doktora tezlerinde kitap ve dergilere aynı oranda (\%47) atıf yapılmasına karşılık, yüksek lisans tezlerinde kitaplara yapılan atıflar (\%52) dergilere yapılan atıflardan (\%38) daha fazladır. Başka ülkelerde tamamlanan kütüphanecilik tezlerinde de atıfların önemli bir kısmının (\%43) kitaplara yapıldığı görülmektedir (LaBorie ve Halperin, 1976, s. 278). Öte yandan, kütüphanecilik tezlerinde atıf yapılan kaynak türleriyle makalelerde atıf yapılanların birbirinden pek farklı olmadığı anlaşılmaktadır. Türk Kütüphaneciliği dergisinde 1987-2001 yılları arasında yayımlanan makalelerin kaynakçalarında yer alan atıfların ya- 
yın türlerine göre dağılımının incelendiği bir araştırmada toplam atıfların \%53'ünün kitaplara, \%42'sinin dergilerde yayımlanan makalelere yapıldığı ortaya çıkmıştır (Tonta, 2002, s. 282). Söz konusu bulgular kütüphanecilik alanındaki tezlerde ve dergilerde yayımlanan makalelerde önemli bir kaynak olarak halen kitaplara başvurulduğunu göstermektedir.

Tablo 3. Tez Türüne Göre Atıf Yapılan Kaynakların Dağılımı ( $N=7019)$

\begin{tabular}{|c|c|c|c|c|c|c|}
\hline \multirow{2}{*}{$\begin{array}{l}\text { Atıf yapılan } \\
\text { yayın türü }\end{array}$} & \multicolumn{2}{|c|}{ Yüksek lisans } & \multicolumn{2}{|c|}{ Doktora } & \multicolumn{2}{|c|}{ Toplam } \\
\hline & $\mathrm{N}$ & $\%$ & $\mathrm{~N}$ & $\%$ & $\mathrm{~N}$ & $\%$ \\
\hline Dergi & 1576 & 38,4 & 1369 & 47,0 & 2945 & 42,0 \\
\hline Kitap & 2127 & 51,8 & 1371 & 47,0 & 3498 & 49,8 \\
\hline E-yayın & 179 & 4,4 & 38 & 1,3 & 217 & 3,1 \\
\hline Tez & 139 & 3,4 & 102 & 3,5 & 241 & 3,4 \\
\hline Diğer & 84 & 2,0 & 34 & 1,2 & 118 & 1,7 \\
\hline Toplam & 4105 & 100,0 & 2914 & 100,0 & 7109 & 100,0 \\
\hline
\end{tabular}

Tezlerde atıf yapılan tüm kaynakların \%55’i (3859) İngilizce, \%44,6’sı (3131) Türkçe, \%0,4'ü (29) de diğer dillerde yazılmıştır. Yabancı dilde kitap ve dergilere yapılan atıflar (\%52) Türkçe kitap ve dergilere yapılan atıflardan (\%40) daha fazladır. Atıf yapılan yabancı dildeki kaynakların \%99'u (3879 atıfın 3850'si) Ingilizcedir. Kütüphanecilik alanında Türkçe literatür henüz kısıtlı olduğundan, yapılan tezlerde İngilizce yayınlara daha yoğun olarak başvurulduğu ortaya çıkmaktadır. Türkçe dergilere yapılan atıfların \%45'i (1129 atıfın 512'si) Türk Kütüphaneciliği dergisinde yayımlanan makalelere yapılmıştır. Yabancı dildeki tezlere oranla $(\% 0,5)$ Türkçe tezlere daha fazla $(\% 2,9)$ atıf yapılırken, yabancı dilde e-yayınlara $(\% 2,5)$ Türkçe e-yayınlardan $(\% 0,6)$ daha fazla sayıda atıf yapıldığı ortaya çıkmıştır. Bu durumun temel nedeni olarak Türkçe tezlerin yabancı tezlerle karşılaştııldığında kolay erişilebilir olması ve tezlerde kullanılabilecek nitelikteki e-yayınların dilinin İngilizce olması gösterilebilir.

\section{Dergilere Yapılan Atıflar}

Yirmi ya da daha fazla sayıda atıf yapılan Türkçe ve yabancı dildeki dergilerin listesi Tablo 4'te verilmektedir. Yüksek lisans ve doktora tezlerinde en sık atıf yapılan dergi (512 atıf) Türk Kütüphaneciliğidir. Başka bir çalışmada da kütüphanecilik alanında tamamlanan 17 doktora tezinde en sık atıf yapılan 
derginin Türk Kütüphaneciliği olduğu ortaya çıkmıştır (Gökkurt, 1997b, s. 156). Türk Kütüphaneciliğı̉ni 236 atıfla Resmî Gazete izlemektedir. Daha sonra ise College \& Research Libraries, Library Trends, Library Journal, Journal of the American Society for Information Science gibi Social Sciences Citation Index'te dizinlenen kütüphanecilik alanındaki önemli dergiler gelmektedir. Adı geçen yabancı dergilerin, tezlerin incelendiği başka çalışmalarda da en çok atıf yapılan dergiler sıralamasında üst sıralarda yer aldığı görülmektedir. Örneğin, Buttlar'ın (1999, s. 237) çalışmasında en çok atıf yapılan dört dergi (College \& Research Libraries, Journal of the American Society for Information Science, Library Journal, Library Trends) ile bizim çalışmamızda en çok atıf yapılan dört yabancı dergi aynıdır. Gökkurt'un (1997b, s. 156) araştırmasında da en çok atıf yapılan yabancı derginin College \& Research Libraries olduğu görülmektedir.

Türk Kütüphaneciliği ve Resmî Gazete dışında 20 ve daha fazla atıf yapılan tek Türkçe dergi Yeni Yayınlar'dır. Dergilere yapılan toplam 2945 atıfın \%60'ı Tablo 4'te verilen 27 dergide yayımlanan makalelere yapılmıştır.

Tablo 4'teki en sık atıf yapılan dergiler ile Türk Kütüphaneciliği dergisinde atıf yapılan kaynakların incelendiği iki çalışmadaki (Kurbanoğlu, 1996; Tonta, 2002) en sık atıf yapılan dergiler arasında benzerlik görülmektedir. Sıralama farklı olmakla birlikte Tablo 4'teki ilk 10 derginin dokuzu Kurbanoğlu'nun, sekizi Tonta'nın çalışmasında en sık atıf alan dergiler arasında yer almaktadır. Tablo 4'te ilk 10 sırada olup, Tonta'nın çalışmasında en sık atıf yapılan dergiler arasında yer almayan kaynaklar Bulletin of the Medical Library Association ve International Library Review'dir. Bulletin of the Medical Library Association adlı dergi Kurbanoğlu'nun çalışmasında da en sık atıf alan dergiler arasında değildir.

Çalışmamızda, bir derginin ISI tarafından saptanan etki faktörünün yüksek olması ile o dergiye kütüphanecilik tezlerinde daha fazla sayıda atıf yapılıp yapılmadığı araştırılmış, ikisi arasında istatistiksel açıdan anlamlı bir ilişki olmadığı görülmüştür (Pearson's $r=.197, p=.28$ ). Aynı test 20 ve daha fazla sayıda atıf yapılan yabancı dilde dergiler için de yapılmış, ancak etki faktörüyle kütüphanecilik tezlerinde dergilere yapılan atıf sayısı arasında istatistiksel yönden anlamlı bir ilişki gözlenmemiştir (Pearson's $r=.144, p=.64$ ). Dergiler için ISI tarafından saptanan etki faktörü katsayılarının, kütüphaneci- 
Tablo 4. En Sık Atıf Yapılan Dergiler

\begin{tabular}{|c|c|c|}
\hline Sıra no & Atıf sayısı & Dergi adı \\
\hline 1 & 512 & Türk Kütüphaneciliği \\
\hline 2 & 236 & Resmî Gazete \\
\hline 3 & 102 & College \& Research Libraries \\
\hline 4 & 99 & Library Trends \\
\hline 5 & 79 & Library Journal \\
\hline 6 & 60 & Journal of the American Society for Information Science \\
\hline 7 & 54 & Unesco Bulletin for Libraries \\
\hline 8 & 48 & IFLA Journal \\
\hline 9 & 43 & Bulletin of the Medical Library Association \\
\hline 9 & 43 & International Library Review \\
\hline 11 & 42 & Aslib Proceedings \\
\hline 11 & 42 & Library Quarterly \\
\hline 13 & 40 & Libri \\
\hline 13 & 40 & Journal of Documentation \\
\hline 15 & 35 & Information Technology \& Libraries \\
\hline 16 & 33 & Special Libraries \\
\hline 17 & 31 & Annual Review of Information Science \& Technology \\
\hline 18 & 30 & Yeni Yayınlar \\
\hline 19 & 26 & School Librarian \\
\hline 19 & 26 & Journal of Librarianship \& Information Science \\
\hline 21 & 25 & Wilson Library Bulletin \\
\hline 22 & 24 & Library Resources \& Technical Services \\
\hline 23 & 23 & International Cataloguing \\
\hline 24 & 22 & Reference Quarterly \\
\hline 25 & 21 & Journal of Education for Library \& Information Science \\
\hline 25 & 21 & School Library Journal \\
\hline 27 & 20 & Library Association Record \\
\hline
\end{tabular}


lik tezlerinde söz konusu dergilere yapılan atıf sayılarının tahmin edilmesinde yararlı bir ölçüt olmadığı anlaşılmaktadır.

Kütüphanecilik tezlerinde 438 ayrı dergide yayımlanan makalelere toplam 2945 atıf yapıldığı görülmektedir. Bu dergilerin 299'u yabancı dilde, 139'u ise Türkçedir. Yüksek lisans tezlerinde 277 farklı dergide yayımlanan toplam 1576 makaleye, doktora tezlerinde ise 267 farklı dergide yayımlanan toplam 1369 makaleye atıf yapılmıştır. Hem yüksek lisans hem de doktora tezlerinde kullanılan dergi sayısı 106'dır. Bu dergilerin 79'u yabancı dilde, 27'si ise Türkçe yayımlanmaktadır. Yüksek lisans tezlerinde en sık atıf yapılan dergiler ile doktora tezlerinde en sık atıf yapılan dergilerin sıralamaları arasında orta düzeyde ve istatistiksel açıdan anlamlı bir ilişki olduğu gözlenmiştir (Spearman's rho $=.563, p<.01$ ). Bazı dergiler hem yüksek lisans hem de doktora tezlerinde en sık atıf yapılan dergiler arasında yer almaktadır.

Yüksek lisans tezlerinde atıf yapılan yabancı dergilerin sıralaması ile doktora tezlerinde atıf yapılan yabancı dergilerin sıralaması arasında orta düzeyde ve istatistiksel açıdan anlamlı bir ilişki olduğu saptanmıştır (Spearman's $r h o=.619, p<.01$ ). Yüksek lisans tezlerinde atıf yapılan Türkçe dergiler ile doktora tezlerinde atıf yapılan Türkçe dergilerin sıralaması arasında ise istatistiksel açıdan anlamlı bir ilişki gözlenmemiştir (Spearman's $r h o=.251, p=.20)$. Bunun nedeni, bazı Türkçe dergilere herhangi bir tezde çok sık atıf yapılırken, aynı dergilere diğer tezlerde daha seyrek atıf yapılması olabilir.

Şekil 2'de yabancı dilde ve Türkçe 438 dergide yayımlanan makalelere yapılan toplam 2945 atıfın dergi sayısına göre birikimli dağılımı verilmektedir. Toplam atıfların \%32'si dört, \%67'si 38 ayrı dergide yayımlanan makalelere yapılmıştır. Dergilerin büyük çoğunluğunda yayımlanan makalelere pek seyrek atıf yapılmıştır. Örneğin, 226 dergide (atıf yapılan toplam dergi sayısının yaklaşık yarısı) yayımlanan makalelere sadece birer kez (toplam atıfların \% $\left.{ }^{\prime} \mathrm{i}\right), 76$ dergide yayımlanan makalelere ise sadece ikişer kez (toplam atıfların \%5’i) atıf yapılmıştır. 


\section{Şekil 2. Atıfların Dergi Sayısına Göre Dağılımı}

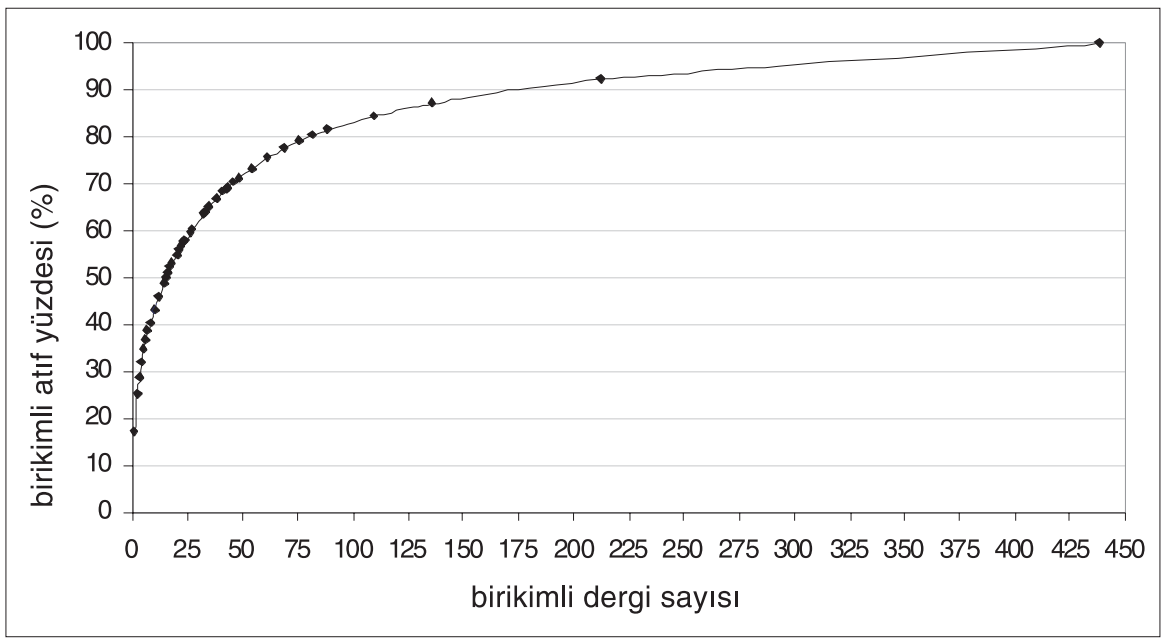

Atıfların dergilere göre dağııımının Bradford'un Saçılım Yasasına uygun olup olmadığı hem tüm dergilerde yayımlanan makaleler, hem de yabancı dilde ve Türkçe dergilerde yayımlanan makaleler için ayrı ayrı test edilmiştir. Öncelikle dergiler atıf sayısına göre kabaca üç eşit gruba ayrıımıştır. Toplam atıfların \%32'si en sık atıf yapılan (949 atıf) dört, \%35'i orta sıklıkta atıf yapılan (1023 atıf) 34, \%33'ü (973 atıf) ise seyrek atıf alan 400 dergide yayımlanan makalelere yapılmıştır.

Yabancı dilde ve Türkçe dergilerde yayımlanan makalelere yapılan atıflar ayrı ayrı tablolaştırımıştır. Türkçe dergilere yapılan 1129 atıf toplam 139 dergide yer alan makalelere yapılmıştır. Ancak Türkçe dergilere yapılan atıfların \%45'i Türk Kütüphaneciliğınnde yayımlanan makalelere, \%21 ise Resmî Gazete'ye yapılmıştır. Yedi Türkçe dergiye yapılan atıflar Türkçe dergilere yapılan toplam atıfların \%75'ine karşılık gelmektedir. Söz konusu dergiler Türk Kütüphaneciliği, Resmî Gazete, Yeni Yayınlar, Türk Dili, Pazarlama Dünyası, Amme Idaresi Dergisi ve Mimarlık adlı dergilerdir. Dergilere yapılan atıf sayısının çokluğu o dergiye atıf yapan yazar sayısının da çok olduğu anlamına gelmemektedir (Kurbanoğlu, 1996, s. 109). Bizim çalışmamızda da 
(özellikle Türkçe dergilere yapılan atıflarda) aynı sonuç elde edilmiştir. Bazı tezlerde kullanılan makalelere konu gereği sadece bir tezde ama çok sayıda atıf yapılabilmektedir. Örneğin, Pazarlama Dünyası adlı dergiye yapılan atıfların tamamı bir tezden gelmektedir. Mimarlık dergisine yapılan 10 atıfın dokuzu aynı kişinin yüksek lisans ve doktora tezlerinde yer almaktadır. Dergilerdeki atıfların incelendiği çalışmalarda da (Kurbanoğlu, 1996, s. 109; Tonta, 2002, s. 301) benzer durumlarla karşılaşıldığı görülmektedir. Türkçe dergilere yapılan atıfların \%45'inin Türk Kütüphaneciliğ’’ne yapılması bu derginin kütüphanecilik alanında uzun süre tek dergi olarak yayımlanmış olmasından kaynaklanmaktadır. Atıfların Türkçe dergilere göre dağılımı Bradford Saçılım Yasasına uymamaktadır.

Yabancı dilde yayımlanan 299 dergiye 1816 atıf yapılmıştır (Tablo 5). Yapılan atıfları üç eşit gruba ayırdığımızda toplam 1816 atıfın 612'sinin (\%34) on, 600'ünün 27 (\%33), 604'ünün de 262 (\%33) dergide yayımlanan makalelere yapıldığı görülmüştür. En sık ve orta sıklıkta atıf yapılan dergi sayıları Bradford Saçıım Yasasına uymaktadır. Seyrek atıf yapılan dergi sayısı ise öngörülenden daha fazla çıkmışıı. Başka bir deyişle, daha büyük bir grup dergiye daha az sayıda atıf yapılmıştır. Az sayıda atıf yapılan dergilerin daha büyük bir grup oluşturması eğilimine diğer araştırmalarda da rastlanmaktadır (Garfield, 1980, s. 6). Yabancı dildeki toplam 150 dergiye sadece birer kez atıf yapılmıştır (yabancı dergilerdeki makalelere yapılan atıfların \%8,3'ü, toplam yabancı dergilerin \%50,2'si). Başka bir çalışmada da atıf yapılan dergilerin benzeri bir dağılım gösterdiği gözlenmiş, toplam atıfların \%34'ü 13, \%32'si 32, geriye kalan \%34'ü ise 186 farklı dergide yayımlanan makalelere yapılmıştır (Tonta, 2002, s. 305). Yapılan atıflardan anlaşıldığı üzere kütüphanecilik alanında az sayıda çekirdek dergi daha sık kullanılmaktadır.

Tablo 5. Yabancı Dergilere Yapılan Atıfların Dağııımı $(N=1816)$

\begin{tabular}{lrrrrr}
\hline & \multicolumn{2}{c}{ Dergi sayıSI } & & \multicolumn{2}{c}{ Atıf sayısı } \\
\cline { 2 - 3 } \cline { 5 - 6 } Grup & $\mathrm{N}$ & & \multicolumn{2}{c}{$\mathrm{N}$} & $\%$ \\
\hline 1 & 10 & 3,3 & & 612 & 33,7 \\
2 & 27 & 9,0 & & 600 & 33,0 \\
3 & 262 & 87,7 & & 604 & 33,3 \\
Toplam & 299 & 100,0 & & 1816 & 100,0 \\
\hline
\end{tabular}




\section{Kütüphanecilik Literatürünün Eskimesi}

Çalışmamızda tezlerde yapılan atıfların yarı yaşamı hesaplanmış ve kütüphanecilik literatürünün genel olarak yaşlanma hızı bulunmuştur. Ayrıca atıf yapılan yayının türüne göre yarı yaşam ayrı ayrı hesaplanmıştır.

1974-2002 yılları arasında yapılan tezlerde yer alan toplam 7019 atıf, atıf yapılan kaynağın yayımlandığı yıla göre sıralanmıştır. Atıf yapılan yayın yılları 1790 ile 2002 arasında değişmektedir. Tezlerde atıf yapılan kaynakların yarı yaşamını bulmak için önce bir tezde atıf yapılan tüm kaynakların yayın yılları, atıfların yapıldığı tezin yayın yılından çıkarılmış ve her tez için atıf yapılan kaynakların ortancası bulunmuştur. Tüm tezler için bulunan ortancaların ortalaması (mean half-life) alınarak atıf yapılan tüm literatür için yarı yaşam hesaplanmıştır. Buna göre, yayın türü ayırt edilmeksizin, tezlerde atıf yapılan kaynakların yarı yaşamı yaklaşık dokuz $(8,8)$ yıldır. Yani, kütüphanecilik tezlerinde atıf yapılan yayınların yarısı son dokuz yılda yayımlanmıştır. Yüksek lisans tezlerinde daha güncel kaynaklara atıf yapıldığı gözlenmiştir. Yüksek lisans tezlerinde kullanılan kaynaklar için yarı yaşam 8,6 doktora tezlerinde ise 9,6 yıldır.

Kaynaklar türlerine göre ayrılmış ve atıf yapılan yayın türü itibariyle yarı yaşam aynı yöntemle ayrı ayrı hesaplanmıştır. Kitaplar için yarı yaşam 9,3, dergiler için ise 9,6 yıl olarak bulunmuştur. Daha önceki bir çalışmada da Türk Kütüphaneciliği dergisinde yayımlanan makalelerde atıf yapılan kaynakların yarısının son 7-8 yılda yayımlandığı, nispeten daha yaşlı literatüre yapılan atıf sayısının giderek azaldığı gözlenmiştir (Tonta, 2002, ss. 307-308). ${ }^{4}$ Söz konusu çalışmada atıfların yıllara göre dağılımını gösteren şekil ile bu çalışmadaki şekil (bkz. Şekil 3) büyük ölçüde benzerlik göstermektedir (Tonta, 2002, s. 308).

Atıf yapılan dergi ve kitapların yayın diline göre yarı yaşam yılları da hesaplanmışıı. Türkçe dergilerdeki atıfların yarı yaşamı 10 yı iken, yabancı dergiler için bu süre sekiz yıldır. Öte yandan yarı yaşam, Türkçe kitaplar için sekiz, yabancı dildeki kitaplar için ise 10 yıldır.

\footnotetext{
${ }^{4}$ Bu çalışmada dergi ve kitaplar için ortaya çıkan yarı yaşam rakamı biraz daha büyük olmakla birlikte, tezlerde verilen ayrıntılı literatürün bu rakamın ortaya çıkmasına neden olduğu söylenebilir.
} 
Kütüphanecilik doktora tezlerinde dergilere yapılan atıfların incelendiği bir çalışmada atıfların üçte birinin son sekiz yılda yayımlanan makalelere yapıldığı saptanmıştır (Bayram, 1998, s. 30). Bizim çalışmamızda dergilere yapılan atıfların üçte biri son beş yılda yayımlanan makalelere yapılmıştır. Doktora tezlerinde ise nispeten daha yaşlı kaynaklara atıf yapıldığı ortaya çıkmıştır.

Şekil 3. Atıfların Yıllara Göre Dağııımı ( $N=7019)$

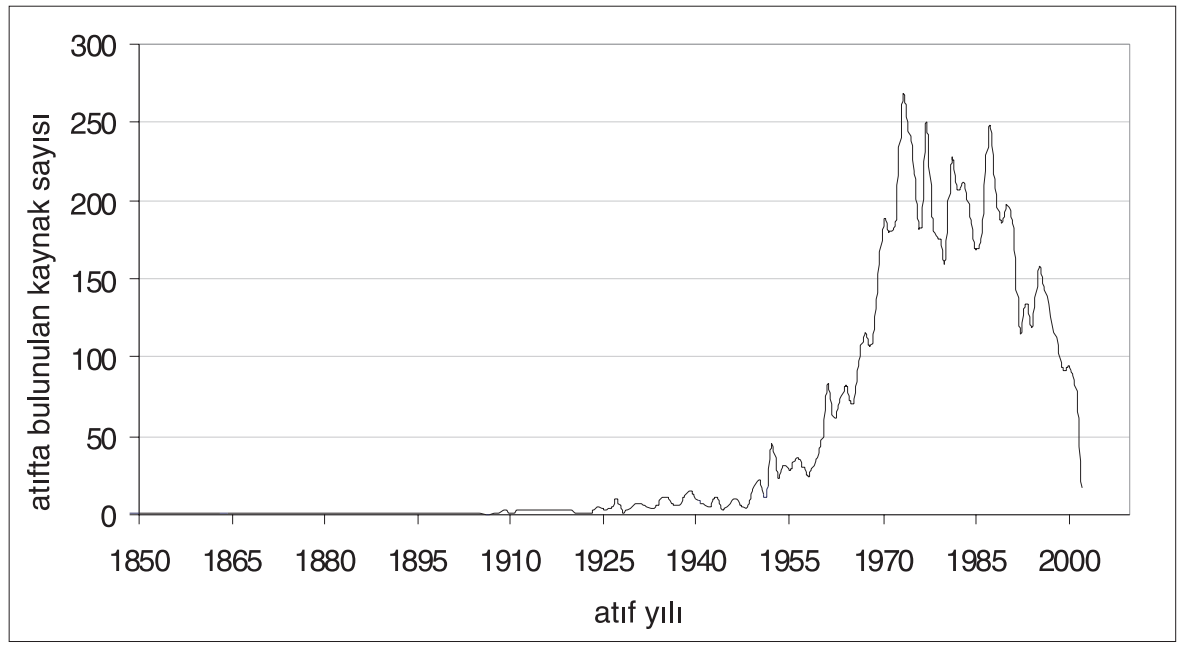

Yabancı literatürde de tezlerde yer alan atıfların eskime rakamlarının verildiği çalışmalar bulunmaktadır. Bunlardan kütüphanecilik tezlerinin incelendiği bir çalışmada (LaBorie ve Halperin, 1976, s. 280) 0-5 yaş arası kaynaklara $\% 24,6-10$ yaş arası kaynaklara \%12, 11-20 yaş arası kaynaklara \%13 ve 20 yaş üzeri kaynaklara ise \%51 oranında atıf yapıldığı saptanmıştır. Bizim çalışmamız ile karşılaştıııldığında, araştırmamız kapsamındaki tezlerde nispeten daha genç kaynaklara atıf yapıldığı görülmektedir. Bunun nedeni, kanımızca, anılan çalışmada tarihsel konularda yapılan tez sayısının yüksek olması ve dolayısıyla atıf yapılan yayınların nispeten daha yaşlı olmasıdır.

Kütüphanecilik Bölümündeki tezlerde yer alan atıfların \%80 ve \%90 yaşlanma/eskime oranları (obsolescence rates) sırasıyla 17 ve 23 yıl olarak hesaplanmıştır. Bir başka ifadeyle, tezlerdeki atıfların \%80'i son 17 yılda, 
\%90'ı ise son 23 yılda yayımlanan kaynaklara yapılmıştır. Yüksek lisans tezlerinde atıf yapılan kaynakların $\% 80$ ve \%90 yaşlanma oranları (sırasıyla 16 ve 22 yıl) doktora tezlerininkinden (sırasıyla 20 ve 26 yıl) daha düşüktür. $\mathrm{Bu}$ bulgular daha önce yarı yaşam için elde edilenlerle benzerlik göstermektedir. Yüksek lisans tezlerinde nispeten daha güncel kaynaklara atıf yapılmaktadır. Atıf yapılan kaynakların yıllara göre dağılımı geniş bir yelpazeye yayılmış olsa da (1790-2002), yüksek lisans ve doktora tezlerinin büyük bir çoğunluğunda son 23 yılda yayımlanan kaynaklardan yararlanıldığı ortaya çıkmaktadır.

\section{Atıf Yapılan Yazarlar}

Tezlerde atıf yapılan kaynakların \%23'ünün (1589 atıf) ya yazarı bulunmamaktadır ya da yazarı tüzel kişidir. Atıf yapılan ve yazarı olan kaynakların (5430) büyük bir çoğunluğu (\%86) tek yazarlı, \%11'i iki yazarlı, \%2'si üç yazarlı, \%1'i ise dört ve daha fazla yazarlıdır. Atıf yapılan kaynaklar içinde birden çok yazarı olan yayınlara yapılan atıflar toplam atıfların \%14'ünü oluşturmaktadır. Atıf yapılan kaynakların ortalama yazar sayısı 1,2 civarındadır. Bu rakam 1970-1999 yılları arasında Social Science Citation Index'te dizinlenen Türkiye adresli kütüphanecilikle ilgili makalelerdeki ortalama yazar sayısına $(1,3)$ çok yakındır (Gülgöz ve diğerleri, 2002).

ABD'de kütüphanecilik alanındaki doktora tezlerinde atıf yapılan kaynakların yazar sayısını inceleyen bir çalışmada tek yazarlı yayınlara yapılan atıfların oranı \%80, iki yazarlı yayınlara yapılan atıfların oranı \%16, üç ve daha fazla yazarlı yayınlara yapılan atıfların oranı ise \%4 olarak bulunmuştur (Buttlar, 1999, ss. 234-235).

Kütüphanecilik Bölümünde son yıllarda yapılan tezlerde çok yazarlı yayınlara nispeten daha fazla atıf yapıldığı görülmektedir. Örneğin, 1974-2002 yılları arasında tamamlanan 100 tezde çok yazarlı yayınlara yapılan toplam 754 atıfın yaklaşık üçte biri (245) son üç yılda tamamlanan tezlerden gelmektedir. Bunun nedeni son yıllarda birden çok yazarlı yayın sayısında yavaş da olsa görülen artıştır. Ancak, diğer sosyal bilim dallarında olduğu gibi, kütüphanecilikte de tek yazarlıığın yaygın olduğu görülmektedir. Disiplinlerarası bir çalışma alanı olan kütüphanecilikte destekli araştırmalar arttıkça kanımızca ortaklaşa yapılan yayın sayısı daha da artacaktır. 
Çalışmamızda, tezlerde atıf yapılan kaynaklardan yazarları Türk olanlar ayrıca incelenmiştir. Yabancı yazarlara yapılan atıfların dağılımının geniş bir yelpazede olacağı düşünülerek sadece Türk yazarlara yapılan atıflara bakılmıştır. Tezlerde 787 farklı Türk yazara ait toplam 1901 kaynaktan yararlanılmıştır. Yazarı bulunan kaynaklar içinde her 100 atıftan 35’i yazarı Türk olan yayınlara yapılmıştır. Bunun nedeni kanımızca Türk kökenli yazarların literatüre katkılarının sınırlı olmasıdır.

Atıfların üçte biri 20, yarısından fazlası ise 74 farklı yazarın yayınlarına yapılmıştır. Geriye kalan 700'den fazla yazarın yayınları ise toplam atıfların sadece yarısını alabilmiştir. Başka bir deyişle, Türkiye'de kütüphanecilik literatürü nispeten az sayıda araştırmacının katkılarından oluşmakta, bu araştırmacıların yayınlarına çok sayıda atıf yapılmaktadır. Tezlerde en çok yararlanılan dergi olan Türk Kütüphaneciliği’nde 1987-2001 yılları arasında toplam 94 farklı yazarın literatüre katkıda bulunmuş olması (Tonta, 2002, s. 291) bu düşüncemizi desteklemektedir. Üstelik dergi hakemli olduktan sonra (1996) toplam yazar sayısı da 54'e düşmüştür (Tonta, 2002, s. 293).

\section{Sonuç ve Öneriler}

Hacettepe Üniversitesi Kütüphanecilik Bölümünde yapılan tezlerde daha çok kitaplara atıf yapıldığı, atıf yapılan kaynakların yarısından fazlasının İngilizce kaynaklardan oluştuğu görülmektedir. Doktora tezleri yüksek lisans tezlerinden yaklaşık iki kat daha uzundur; kaynakçaları da 2,5 kat daha fazla atıf içermektedir. Öte yandan yüksek lisans tezlerinde son yıllarda yayımlanan literatüre daha sık atıf yapılmaktadır. Bu sonuçların ortaya çıkmasına bir yüksek lisans tezi ile bir doktora tezine yönelik beklentilerin birbirinden farklı olmasının neden olduğu düşünülmektedir.

Hacettepe Üniversitesi Kütüphanecilik Bölümünde yılda ortalama üç tez tamamlanmaktadır. Kanımızca bu rakam düşüktür. Günümüzde bilgi merkezlerinin, kütüphanelerin ve arşivlerin karşı karşıya kaldıkları bilgi yönetimiyle ilgili sorunların az sayıda yüksek lisans ve doktora derecesine sahip olan meslek mensuplarıyla çözülebilmesi mümkün gözükmemektedir. İlgili bölümlerde daha fazla sayıda tez çalışması yapılmalıdır.

Kütüphanecilik literatürüne katkıda bulunan Türk kökenli yazar sayısı düşüktür. Daha çok yazarın literatüre katkıda bulunması gerekmektedir. 
Tezlerde az sayıda Türk yazarın belirli yayınlarına sık sık atıf yapıldığı görülmektedir. Benzeri bir biçimde az sayıda dergide yayımlanan makalelere çok sayıda atıf yapıldığı, dergilerin çoğunda yayımlanan makalelere nadiren atıf yapıldığı gözlenmiştir. Atıf analizi çalışmalarından yararlanılarak en sık atıf yapılan yayınların listesi oluşturulmalıdır.

Tezlerde atıf yapılan kaynaklar arasında bilgibilim alanı dışındaki kaynaklara seyrek rastlanmaktadır. Doğrudan araştırma yapılan konularla ilgili olan bu durum, giderek disiplinlerarası çalışmanın önem kazandığı günümüz şartlarında bir eksiklik olarak göze çarpmaktadır. Öğrenciler, önemli olduğu düşünülen disiplinlerarası konularda araştırma yapmak üzere cesaretlendirilmelidirler.

Kütüphanecilik alanında en sık atıf yapılan dergiler saptanarak bir çekirdek dergi koleksiyonu oluşturulabilir. En sık atıf yapılan ve kullanılan dergi listesinde yer alan dergilerin mümkünse eski sayılarına da erişim sağlanmaııdır. Literatür saçılımı ve eskimesi olguları çeşitli alanlar için ayrı ayrı araştırılarak, abone olunacak dergiler ve elektronik dergilere erişim lisanslarının hangi yıllara dek geriye gitmesi gerektiği hakkında politikalar geliştirilmelidir. Benzeri bir biçimde atıf analizi çalışmalarına dayanarak nispeten seyrek kullanılan dergiler için de politikalar oluşturulmalıdır. Atıf analizi çalışmaları bibliyografik eşleştirme ve ortak atıfların analizini de kapsamalı, elde edilen bulgular kütüphane içi kullanım istatistikleriyle de desteklenmelidir.

\section{Kaynakça}

Alkan, N. (1998). Temel ve uygulamalı bilim dallarında etki faktörü değeri en yüksek olan süreli yayınların Ankara'daki üniversite kütüphanelerinde bulunabilirliği. Türk Kütüphaneciliği, 12, 279-305.

Alkan, N. (1999). Tıp ve sağlık bilimleri dallarının 1990'larda etki faktörü değeri en yüksek olan süreli yayınları ve bunların Ankara'daki ilgili kütüphanelerde bulunabilirliği. Ö. Bayram, E. Erkan, T. Gülle, D. Toplu, M. Toplu ve E. Yılmaz (Yay. Haz.), Bilginin Serüveni: Dünü, bugünü ve yarını..: Türk Kütüphaneciler Derneği'nin Kuruluşunun 50. Yılı Uluslararası Sempozyumu bildirileri: 17-21 Kasım 1999 Ankara içinde (ss. 278-300). Ankara: Türk Kütüphaneciler Derneği. 
Altınörs, G. (1983). Türkiye'de kütüphanecilik bilim dalı konusunda yapılmış olan doçentlik, doktora ve bilim uzmanlığı tezlerinde kullanılmış olan araştırma metodları. Yayımlanmamış yüksek lisans tezi, Hacettepe Üniversitesi, Ankara.

Bayram, Ö. (Gökkurt). (1998). Atıf verisi (citation data) ve enformetrik yasalar: Türk kütüphanecilik literatüründeki doktora tezleri üzerinde bir uygulama. Türk Kütüphaneciliği, 12, 21-32.

Broadus, R. N. (1987). Early approaches to bibliometrics. Journal of the American Society for Information Science, 38, 127-129.

Buttlar, L. (1999). Information sources in library and information science doctoral research. Library and Information Science Research, 21, 227-245.

Çakın, Y. (1980). Türk Kütüphaneciler Derneği Bülteni'nin içerik ve yazar yönünden değerlendirilmesi. Yayımlanmamış yüksek lisans tezi, Hacettepe Üniversitesi, Ankara.

Denkel, A., Kâğıtçıbaşı, Ç., Pak, N. K., ve Pamuk, Ş. (1999). Türkiye'de sosyal bilimlerin uluslararası yayın performansı. Ankara: Türkiye Bilimler Akademisi.

Earle, P. ve Vickery, B. (1969). Social science literature use in the UK as indicated by citations. Journal of Documentation, 25, 123-141.

Edwards, S. (1999). Citation analysis as a collection development tool: A bibliometric study of polymer science theses and dissertations. Serials Review, 25, 11-20.

Garfield, E. (1988). Announcing the SCl compact disc edition: CD-ROM gigabyte storage technology, novel software, and bibliographic coupling make desktop research and discovery a reality. Current Contents, 22, 3-5. 11 Aralık 2003 tarihinde http://www.garfield.library.upenn.edu/ essays/v11p160y1988.pdf adresinden erişildi.

Garfield, E. (1980). Bradford's Law and related statistical patterns. Current Contents, 19, 5-12. 10 Kasım 2003 tarihinde http://www.garfield. library.upenn.edu/essays/v4p476y1979-80.pdf adresinden erişildi. 
Gooden, A. M. (2001). Citation analysis of chemistry doctoral dissertations: An Ohio State University case study. Issues in Science and Technology Librarianship, 32. 24 Temmuz 2003 tarihinde http://www.istl.org/istl/ 01-fall/refereed.html adresinden erişildi.

Gökkurt, Ö. (1997a). "Citation" indeks ve "citation" analizi: Enformetrik bir model çalışması. Yayımlanmamış doktora tezi, Ankara Üniversitesi, Ankara.

Gökkurt, Ö. (1997b). Yoğunlaşma teorisi ve atıf analizinde kullanımı. B. Yılmaz (Yay. Haz.), Kütüphanecilik Bölümü 25. Yıla Armağan içinde (ss. 153-161). Ankara: Hacettepe Üniversitesi.

Gülgöz, S., Yedekçioğlu, Ö. A. ve Yurtsever, E. (2002). Turkey's output in social science publications: 1970-1999. Scientometrics, 55, 103-121.

Gürdal, O. (2002). Altın yılını yaşayan Türk Kütüphaneciliği dergisinden yansımalar. Türk Kütüphaneciliği, 16, 321-328.

Herubel, J-P.V.M. (1991). Philosophy dissertation bibliographies and citations in serials evaluation. Serials Librarian, 20,65-73.

Institute for Scientific Information. (2002). Journal Citation Reports. 21 Eylül 2003 tarihinde http://jcrweb.com adresinden erişildi.

Kum, I. (1974). Türkiye'de tıp kütüphaneleri. Yayımlanmamış doçentlik tezi, Hacettepe Üniversitesi, Ankara.

Kurbanoğlu, S. S. (1996). Türk kütüphanecilerinin kullandığı dergiler. Türk Kütüphaneciliği, 10, 105-118.

Kushkowski, J. D., Parsons, K. A., ve Wiese, W. H. (2003). Master's and doctoral thesis citations: Analysis and trends of a longitudinal study. portal: Libraries and the Academy, 3, 459-479. 22 Eylül 2003 tarihinde http://muse.jhu.edu/journals/portal_libraries_and_the_academy/v003/ 3.3kushkowski.pdf adresinden erişildi.

Kuyper-Rushing, L. (1999). Identifying uniform core journal titles for music libraries: A dissertation citation study. College \& Research Libraries, 60, 153-163. 
LaBorie, T. ve Halperin, M. (1976). Citation patterns in Library Science Dissertations. Journal of Education for Librarianship, 14, 271-283.

Line, M. B. (1970). The 'half-life' of periodical literature: Apparent and real obsolescence. Journal of Documentation, 26, 46-54.

Meadows, A. J. (1967). The citation characteristics of astronomical research literature. Journal of Documentation, 23, 28-33.

Rousseau, R. (1988). Citation distribution of pure mathematics journals.

L. Egghe and R. Rousseau (Ed.). Informetrics 87/88: Select Proceedings of the First International Conference on Bibliometrics and Theoretical Aspects of Information Retrieval: 25-28 August 1987 Diepenbeek, Belgium içinde (ss. 249-262). Amsterdam: Elsevier.

Sengupta, I. N. (1974). Impact of scientific periodicals on the advancement of medical knowledge: An objective method of analysis. International Library Review, 4, 169-195.

Smith, L. C. (1981). Citation analysis. Library Trends, 30, 83-106.

Sylvia, M. ve Lesher, M. (1995). What journals do psychology graduate students need? A citation analysis of thesis references. College \& Research Libraries, 56, 313-318.

Tonta, Y. (2002). Türk Kütüphaneciliği dergisi, 1987-2001. Türk Kütüphaneciliği, 16, 282-320.

Tonta, Y. (2000). Contribution of Turkish researchers to the world's biomedical literature (1988-1997). Scientometrics, 48, 71-84.

Tonta, Y. ve İlhan, M. (2002). Contribution of Hacettepe University Faculty of Medicine to the world's biomedical literature (1988-1997). Scientometrics, 55, 123-136.

Tonta, Y. ve İlhan, M. (1997). Sosyal bilimlerde Türkiye'nin dünyadaki yeri. Türk Psikoloji Dergisi, 12, 67-75.

Walcott, R. (1994). Local citation studies: A shortcut to local knowledge. Science \& Technology Libraries, 14 (3), 1-14.

Walcott, R. (1991). Characteristics of citations in geoscience doctoral dissertations accepted at United States academic institutions 19811985. Science \& Technology Libraries, 12 (2), 5-16. 
White, E. C. (1985). Bibliometrics: From curiosity to convention. Special Libraries, 76 (1), 35-42.

Yılmaz, B. (1997). Hacettepe Üniversitesi Edebiyat Fakültesi Kütüphanecilik Bölümü lisansüstü tezlerinin niceliksel ve konusal analizi: 1974-1997. B. Yılmaz (Yay. Haz.). Kütüphanecilik Bölümü 25. Yıla Armağan içinde (ss. 191-198). Ankara: Hacettepe Üniversitesi.

Yılmaz, M. (2000). Türkiye'de kütüphane ve enformasyon bilimi alanında bilimsel iletişimin meslek dergilerinde yansıması: Bibliyometrik bir analiz. A. Yontar (Yay. Haz.). Türkiye'de Kütüphane ve Enformasyon Biliminin Kurumsal Gelişimi içinde (ss. 29-48). İstanbul: Türk Kütüphaneciler Derneği İstanbul Şubesi.

Yurtsever, E. ve Gülgöz, S. (1999). The increase in the rate of publications originating from Turkey. Scientometrics, 46, 321-336.

Yurtsever, E., Gülgöz, S., Yedekçioğlu, Ö. A., ve Tonta, M. (2002). Sağlık bilimleri, mühendislik ve temel bilimlerde Türkiye'nin uluslararası atıf dizinindeki yeri: 1973-1999. Ankara: Türkiye Bilimler Akademisi.

Yurtsever, E., Gülgöz, S., Yedekçioğlu, Ö. A. ve Tonta, M. (2001). Sosyal Bilimler Atıf Dizini'nde (SSCI) Türkiye: 1970-1999. Ankara: Türkiye Bilimler Akademisi.

Zipp, L. S. (1996). Thesis and dissertation citations as indicators of faculty research use of university library journal collections. Library Resources \& Technical Services, 40, 335-342. 